\title{
LA RESPONSABILIDAD DEL ESTADO POR SECUESTROS DE BIENES EN LA REPÚBLICA CHILENA TEMPRANA*
}

\author{
STATE LIABILITY BASED UPON POLITICAL CONFISCATIONS IN THE \\ EARLY CHILEAN REPUBLIC
}

\begin{abstract}
Gabriel Bocksang Hola*
RESUMEN: La reparación de los secuestros de bienes derivados de las represalias políticas de la Emancipación permitió configurar una de las primeras categorías de sentencias que declararon la responsabilidad del Estado de Chile. La construcción de este régimen fue compleja, y requirió de arduos esfuerzos políticos, que en lo estrictamente jurídico permitieron remediar o mitigar injusticias arrastradas hasta por casi medio siglo.

Palabras clave: Responsabilidad, secuestros, confiscación, Independencia, Chile.

ABSTRACT: Liability based upon "sequestrations" -confiscations- grounded on political retaliations during the process of Independence permitted the configuration of one of the first categories of judicial decisions having declared the liability of the State of Chile. The construction of this régime was complex, and required strenuous political efforts, which strictly in Law allowed mending or mitigating injustices suffered up to almost half a century.
\end{abstract}

Key words: Liability, torts, confiscation, Independence, Chile.

\section{INTRODUCCIÓN}

Hemos tenido la oportunidad de definir el llamado secuestro de bienes como la "sanción administrativa por la cual las autoridades de un régimen en ejercicio privaban de sus bienes a los adversarios políticos, con el doble propósito de amedrentarlos respecto de una eventual rebelión y de recaudar fondos para las arcas públicas" ${ }^{1}$. Dicho secuestro recibió una aplicación particularmente intensa durante los años de la revolución independentista $^{2}$, y en especial durante los primeros años de la llamada Patria Nueva ${ }^{3}$.

\footnotetext{
El presente artículo forma parte del proyecto CONICYT/FONDECYT/INICIACIÓN/No 11121184, "El nacimiento del derecho administrativo chileno (1810-1860)", cuyo investigador responsable es el autor.

** Licenciado en Derecho, Pontificia Universidad Católica de Chile. Máster de Investigación en Derecho Público, Universidad de París 1, Panthéon-Sorbonne. Doctor en Derecho, Universidad de París 1, Panthéon-Sorbonne. Profesor de Derecho Administrativo y Secretario Académico, Pontificia Universidad Católica de Chile. . Correo electrónico: gbocksan@uc.cl.

1 En nuestro trabajo "El secuestro de bienes como primera sanción administrativa del Estado de Chile”, presentado en las X Jornadas de Derecho Administrativo y de próxima publicación en sus actas.

2 Véase, en general, Dávila Campusano (1988), in totum. De acuerdo a Barros Arana (2005) p. 245, la justificación de este mecanismo era meramente bélica: "estaba entonces autorizado por las prácticas de la guerra". Respecto de esta práctica durante la llamada Reconquista, véase GuerRero LiRA (2002), passim pero esp. pp. 260-268.

3 V. gr., Encina (1970), 8a Parte, cap. I, tít. 7: Tomo VII, pp. 316-317.
} 
Resulta muy llamativo constatar la escasa atención que ha merecido este mecanismo por parte de los juristas. Probablemente sea aún ignorado por una gran parte de ellos, así como por la mayoría de nuestros administrativistas. Sin embargo, las luces que arroja son -a la vez- tan dramáticas y tan ilustrativas, que parece indispensable explorar algunas de sus aristas a fin de evitar un incurso similar en el futuro, que pudiere alterar los fundamentos de nuestro régimen republicano.

La contextualización histórica y económica de los secuestros ha merecido ya un estudio penetrante y profusamente documentado ${ }^{4}$. No obstante, existen brechas importantes en lo concerniente a sus aspectos jurídicos, y eminentemente al ius suum cuique tribuere, la atribución debida de lo suyo a cada uno. Privado un sujeto de lo suyo, la única forma de que ello le sea atribuido -o reatribuido- se da a través de la responsabilidad: primariamente, a través de la restitución del bien en cuestión; y secundariamente, de no ser posible la restitución, a través de la correspondiente indemnización.

Ha de subrayarse, como elemento central del presente estudio, que el descalabro económico y jurídico impuesto durante la época de la Emancipación en razón de estos secuestros no fue indiferente para las autoridades republicanas que ejercieron cargos de autoridad una vez cesados los arrebatos febriles de la época bélica.

Aunque ello no significa que todos los daños impuestos torticeramente sobre las respectivas víctimas fueran reparados, sí resulta indiscutible que la autoridad se dio paulatinamente cuenta acerca de la importancia de contar con un mecanismo que permitiera reparar dichos perjuicios, cumplidos los requisitos correspondientes.

El estudio que ha abordado con mayor acuciosidad el tema de la reparación en este ámbito expresa tajantemente que "se conservan escasos vestigios de las reclamaciones por secuestros" . No nos parece conveniente que dicha afirmación sea aceptada de modo literal.

En efecto, ella solo da cuenta de la dificultad a la que cualquier investigador debe enfrentarse para localizar expedientes en que se agitasen asuntos de secuestros. Con seguridad, muchos de estos se encuentran irremediablemente perdidos. Empero, algunos sobreviven en archivos nacionales, ofreciendo datos invaluables sobre la forma en que Chile enfrentó este problema; y en las ediciones de la Gaceta de los Tribunales puede ser consultado un número más que decoroso de sentencias publicadas al respecto. Por lo tanto, las trazas de causas por secuestros no son tan exiguas como podría pensarse, y resulta sorprendente que, transcurridos más de ciento cincuenta años desde su tramitación, guarden aspectos inexplorados.

Las líneas que siguen, tienen por objeto examinar panorámicamente la reparación de los secuestros de bienes, esfuerzo que -a nuestro juicio- se irguió como una de las páginas jurídicas más interesantes de nuestra historia republicana. Pueden distinguirse dos etapas principales en la solución de este grave entuerto: la de las soluciones tempranas (I), y la de la solución decisiva, establecida por la ley de 15 de septiembre de 1853 y pormenorizada a través de las sentencias que la aplicaron (II).

\footnotetext{
Cárdenas Gueudinot (1998), in totum.

5 Cárdenas Gueudinot (1998) p. 287.
} 


\section{LAS SOLUCIONES TEMPRANAS}

La construcción del régimen de responsabilidad del Estado por secuestros le significó un esfuerzo importante a las autoridades nacionales, que debieron conciliar los requerimientos de la justicia con una menguante - pero siempre presente- resistencia a indemnizar a quienes se consideraba como enemigos políticos. Ello sedimentó en que los primeros mecanismos se vieran afectados por una inspiración retributiva, es decir, de recompensa a aquellas personas que revirtiesen su pensamiento político en beneficio del régimen independentista, o de restitución a quienes erróneamente hubieran sido considerados como enemigos políticos.

Estos primeros pasos se consagraron a través de la aplicación de dos etapas sucesivas: una etapa germinal, dominada por el Senadoconsulto de 5 de mayo de 1821, de tendencia derechamente retributiva (a) y una etapa intermedia, dominada por la Ley de Deuda Interior, de 17 de noviembre de 1835, en la que la emersión de una lógica reparatoria, si bien influyente, quedaría suspensa por motivos técnicos (b).

\section{a. LA ETAPA GERMINAL}

El examen de los expedientes sobre secuestros que sobreviven de los primeros años de la Emancipación muestra que, en muchas oportunidades, los litigios respectivos no versaban sobre la reparación de los perjuicios ocasionados, sino que se enfocaban en otros problemas prácticos referidos a ellos ${ }^{6}$. A modo ejemplar, asuntos como la indemnización con bienes secuestrados a un prófugo realista de los perjuicios ocasionados por este a una $v_{\text {víctima }}{ }^{7}$, el pago preferente de las obligaciones de un prófugo fallecido con los bienes que le fueron secuestrados, junto con la transmisión del remanente ${ }^{8}$, y la restitución de bienes que, siendo de propiedad de un patriota, habían sido secuestrados de un realista mero tenedor ${ }^{9}$. En ocasiones la autoridad era capaz de aflojar los rigores atendiendo a consideraciones de equidad, como al decidir la asignación, a título de alimentos, de parte de los intereses producidos derivados del remate de los bienes secuestrados a un realista prófugo, en beneficio de su cónyuge que había permanecido en Chile ${ }^{10}$.

Es importante tener presente que gran parte de las reclamaciones interpuestas durante esta etapa contra secuestros fueron resueltas en definitiva por los Gobernadores Intendentes, que se hallaban bajo el imperio del Director Supremo. Esta dependencia se reveló, en ocasiones, nefasta para particulares que habían vencido al Fisco: el caso más sensible es el de un sujeto cuyos secuestros fueron ordenados ser alzados por el Gobernador Intenden-

\footnotetext{
6 Ello hubiera sido impensable, atendida la calamitosa situación económica del Erario durante este período: véase, v. gr., Barros Arana (2005) p. 246. Para peor, el desorden político de la época impidió que los secuestros efectuados repercutiesen sobre las arcas públicas con el provecho que las autoridades esperaban: SILVA VARGAS (2013) pp. 417-418; como consecuencia, el mecanismo de los secuestros "resultó bastante ineficiente desde un punto de vista tributario y dañino en términos económicos: CÁRdENAS GueUdinOT (1998) p. 296.

7 Pantoja (1817).

8 Vela (1818).

9 Buzeta (1821).

10 Cardemí(1819).
} 
te, orden devenida totalmente ineficaz, pues sucesivamente el "Superior Gobierno" dispuso suspender su cúmplase en razón de que habría habido compensaciones pendientes con el recurrente ${ }^{11}$.

A mediados de 1821 se advirtieron los primeros atisbos de relajación en esta materia $^{12}$. Un elemento interesante es la existencia de un expediente concluido mediante un avenimiento, en el que, incitándose a la enmienda del comportamiento político de un sujeto, se le impuso una pena privativa del dominio de algunos bienes, alzándose el secuestro de todos los restantes ${ }^{13}$.

Pero, por sobre todo, emergió un texto de rango legal que tenía por objeto la restitución de bienes secuestrados: se trata de un Senadoconsulto de 5 de mayo de 1821 que no fue reproducido posteriormente en el Boletín de Leyes y Decretos del Gobierno ${ }^{14}$. En razón de su desconocimiento y de su importancia, parece conveniente reproducirlo en estas líneas.

"En la sesión ordinaria de este día, acordó S. E. debía observarse por ley inviolable que en el caso de haberse secuestrado bienes de particulares en el equivocado concepto de ser sus propietarios emigrados enemigos de la libertad del país, y se acreditase de un modo auténtico el error padecido, deberá ejecutarse la devolución, pero sin cargo de reintegrarse por el Erario los frutos y proventos que haya percibido como procedentes de esos bienes, quedando solo a salvo el dueño, el derecho de pedir por la subsanación de perjuicios contra el que, o los que hubiesen informado con falsedad contra su opinión y conducta política; y si aconteciere que algún enemigo de la causa de América, emigrado en odio de ella, vuelve al país, y manifestándose arrepentido acreditare de un modo indudable que, procediendo de buena fe, quiere unirse a nuestra gran familia, podrá el Supremo Gobierno deliberar sobre la devolución en todo o en parte de lo que se le hubiere secuestrado, consideradas las circunstancias de utilidad, y conveniencias que pueden venir al Estado de la aceptación de los votos, protestas y comprometimientos del arrepentido".

Su naturaleza es bien peculiar. En su primera parte, declara la protección de los bienes de quienes no fueran "propietarios emigrados enemigos de la libertad del país", por lo que si los sujetos hubieran sido privados de sus bienes, estos se les restituirían sin los "fru-

\footnotetext{
11 Zapata (1823).

12 Augurados por un texto anterior específicamente dirigido a la Intendencia de Concepción: el Decreto [Senadoconsulto] de Amnistía, de 8 de febrero de 1819, para la restitución de las provincias de la Intendencia de Concepción al Estado de Chile (Boletín de Leyes y Decretos del Gobierno, en adelante BLDG [1819-1820], p. 19, cuyo artículo $2^{\circ}$ disponía que "No se confiscará ni secuestrará propiedad alguna de habitantes de Concepción que se hayan retirado involuntariamente con el enemigo [aludiéndose al retiro forzado de la población hacia el sur del Biobío en 1818, ordenado por el coronel Sánchez], y existan bajo su dominio, ínterin no conste de un modo legal, que han tomado las armas contra la causa de la patria en esta última campaña; o que pudiendo no se restituyan a sus hogares dentro de treinta días después de la publicación de esta amnistía”.

13 Recabarren (1821).

14 Sí puede hallarse en la Gazeta Ministerial de Chile, tomo 2, no 92.
} 
tos y proventos" percibidos ${ }^{15}$. Como se advierte, persistía el factor político como criterio para una eventual devolución, el que se manifiesta rutilantemente en la segunda parte del documento. Esta incitaba al arrepentimiento de los realistas prófugos, permitiendo discrecionalmente una restitución cuando ellos justificasen fehacientemente su ulterior lealtad a la causa patriota. Las expresiones allí vertidas muestran más una suerte de extorsión política para afirmar la causa de la Independencia que un medio de genuina reparación de un daño causado: su lógica, en consecuencia, era retributiva y no genuinamente reparatoria.

A partir de entonces, los sucesivos gobiernos se empeñaron, con resultados diversos, en superar el trauma y sus consecuencias jurídicas y políticas.

En cuanto a la deuda interior de la República -en la que hubiera cabido contar las deudas por secuestros, como finalmente fue el caso-, un primer proyecto general fue presentado en 1825 por el Director Supremo Ramón Freire ${ }^{16}$, pero parece haber perecido rápidamente en su tramitación. Queda de él, sin embargo, el testimonio de las propias palabras de Freire sobre la importancia de saldar las deudas existentes: "crear rentas fijas, hacer que todo ciudadano contribuya en proporción a sus facultades, reconocer la República sus deudas, y pagar un justo interés mientras que no le es posible amortizarlas; he aquí las bases en que se fundan las leyes propuestas. ¿Podrá desconocerse su utilidad? ¿Podrán los pueblos negarse a su admisión?"17.

Posteriormente, el 10 de julio de 1827 vio la luz un decreto firmado por el Vicepresidente Pinto que disponía una regulación extensa concerniente a la "Liquidación de la deuda interior". Si bien este no parece haber tenido una influencia decisiva para solucionar el problema de los secuestros, conviene destacar que el numeral $1^{\circ}$ disponía que "todas las deudas del Estado, cualquiera que sea su naturaleza y condición, desde el tiempo del gobierno español hasta el 18 de setiembre de 1810, y de esta época hasta el 30 de abril del presente año, serán reconocidas y registradas en el libro de la deuda nacional interior" 18 . Sin mencionar el lastre de los secuestros de bienes, debiera entenderse que la redacción de la oración transcrita las comprendía. El gobierno intentó dar en un corto plazo a todas estas deudas una solución definitiva, estableciendo un término de seis meses para exigir su pago a la Caja de Descuentos, contado desde el 1 de agosto de $1827^{19}$. Empero, el Gobierno parece haber subestimado la magnitud del problema, pues se vio forzado a prorrogar el plazo hasta 1829 en sucesivas oportunidades ${ }^{20}$.

\footnotetext{
15 En la época también se examinaban los casos en que existían privaciones no calificables propiamente como secuestros: véase, muy claramente, Olave (1823).

16 Sesiones de los cuerpos legislativos de la República de Chile (recopilación de Valentín Letelier; en adelante $S C L), t$. $X$, p. 224: "se leyó un oficio del Ejecutivo, acompañando dos proyectos, uno sobre la contribución directa y otro sobre la consolidación de la deuda, y se mandó pasar a la Comisión de Hacienda”.

17 Sesiones de los Cuerpos Legislativos de la República de Chile, t. X, p. 225.

18 Boletín de Leyes y de Decretos del Gobierno, III (1826-1827), p. 135. Las cursivas son nuestras.

19 Numeral 3o del mismo decreto.

20 Decreto de 15 de enero de 1828, que prorrogó por cuatro meses más el anterior plazo de seis, en Boletín de Leyes y de Decretos del Gobierno, IV (1828 - marzo de 1830), p. 14; Decreto de 10 de octubre de 1828, que dispuso seis meses adicionales, en Boletín de Leyes y de Decretos del Gobierno, IV (1828 - marzo de 1830), p. 47; Decreto de 3 de abril de 1829, estableciendo otros seis meses, en IV (1828 - marzo de 1830), p. 118.
} 
En lo que respecta a la vía judicial, suprimida a partir de 1823 la antigua competencia de los Gobernadores Intendentes y de la Junta Contenciosa de Hacienda, se empieza a advertir una mayor independencia en el juzgamiento de las causas de secuestros por la justicia ordinaria. Un momento importante está dado por la sentencia Fisco con Ruiz de 1825, recaída en un expediente en que el Fisco pidió que un particular le entregara un número elevado de vacas en razón de corresponderle por ser en la especie bienes sujetos a secuestros. Contra todos los empeños de los Ministros del Tesoro, el juez de letras desestimó las alegaciones acerca de que el particular hubiera sido un realista -lo que hubiera justificado ipso facto el secuestro de las vacas- o de que las vacas hubieran sido robadas a otros particulares en medio de la confusión posterior a la batalla de Maipú ${ }^{21}$, declarando la propiedad del particular sobre ellas.

De aquí en adelante, constan sentencias de disímil valía. Algunas garantistas, disponiendo el alzamiento de secuestros de generosa cuantía ${ }^{22}$, o la posibilidad de probar con diferentes medios probatorios que el inmueble que solo arrendaba un enemigo político era en realidad propiedad de un tercero patriota ${ }^{23}$. Otras, bastante cuestionables, como la orden de devolución de diversos bienes a un particular, en razón de un secuestro injusto, siempre que tal devolución no significara "nuevo gravamen o responsabilidad al Erario"24.

La vía legislativa de la restitución de bienes secuestrados se reactivó a partir de 1830, con la aprobación por el Congreso de Plenipotenciarios -el 14 de septiembre- de la devolución de los bienes que habían sido confiscados por las municipalidades de Santiago y Concepción a los regulares de órdenes religiosas ${ }^{25}$. Aunque la restitución era debida, los móviles que permitieron disponerla no fueron los más inmaculados: "el Erario se halla hoy notablemente reagravado porque el producido de los bienes enajenados se consumió, y los réditos que pagan los censuarios y arrendatarios no pueden llenar las congruas de los secularizados, ni las asignaciones mensuales de los que no han dejado el claustro" ${ }^{26}$.

Simultáneamente, también los tribunales de justicia dieron señales de que la etapa germinal de devolución de secuestros, influida fuertemente por factores políticos, comenzaba a verse superada. La notable sentencia Freire, de 1831, tuvo por objeto la devolución de la Hacienda Cuchacucha, que había sido secuestrada a Alejandro Urrejola y entregada a Ramón Freire en 1822 como premio a sus servicios por la patria. La Corte de Apelaciones, juzgando que la escritura de donación de Cuchacucha a Freire era "sin valor y efecto", or-

\footnotetext{
21 Fisco con Ruiz (1825).

22 Beltrán (1827).

23 Ministros del Tesoro con Ávila (1830). La resolución de primera instancia, correspondiente a la época de los Gobernadores Intendentes, le exigía a Ávila para la prueba del dominio la exhibición de una escritura, que en esos tiempos no era de la esencia del contrato.

24 Vildósola (1828).

25 Boletín de Leyes y de Decretos del Gobierno, V (abril de 1830-1832), p. 69. "Entréguense a los regulares sus temporalidades, a excepción de las que hayan sido enajenadas con autorización de los cuerpos legislativos" (art. 2o). Véase sobre este tema WestermeYer HernÁndez (2010) p. 1127.

26 Boletín de Leyes y de Decretos del Gobierno, V (abril de 1830-1832), p. 69; también en Sesiones de los Cuerpos Legislativos de la República de Chile, t. XVIII, p. 475.
} 
denó restituir el fundo a los herederos de $\mathrm{Urrejola}^{27}$, reservándosele el derecho a Freire para pedir "donde corresponda" la indemnización que reclamaba ${ }^{28}$.

Atendido todo lo anterior, el Gobierno del Presidente José Joaquín Prieto se propuso abordar definitivamente el problema de los secuestros de bienes. El primer apronte del Presidente Prieto apuntó a readecuar la legislación ya existente, dada eminentemente por el referido Senadoconsulto de 5 de mayo de 1821. Así, el 7 de septiembre de 1832 en la Cámara de Senadores se dio cuenta acerca de una primera preocupación en este sentido ${ }^{29}$ : un oficio presidencial ${ }^{30}$ que tenía por objeto específico el de modificar el referido Senadoconsulto, a fin de que los bienes no fueran devueltos por gracia del Gobierno, sino por una "estricta administración de Justicia"31.

La lectura de este oficio resulta muy interesante, pues refleja la consternación que produjo sobre el presidente Prieto el descubrimiento de que los secuestros de bienes habían tenido un carácter propiamente confiscatorio, y no meramente cautelar o preventivo. Notando que en el Senadoconsulto se consideraba como criterio para la devolución de los bienes la calificación o no del sujeto en cuestión como "enemigo de la libertad del país", el Presidente Prieto expresó que "según esto, parece que el espíritu de esa ley fuera adjudicar al Fisco en dominio y propiedad los bienes de los emigrados cuya enemistad al país fuese cierta y efectiva, pues de otro modo es inútil la condición que se pone de que se haga la devolución en el caso de que los bienes hubiesen sido secuestrados en el equivocado concepto de que sus dueños eran contrarios a la causa de Chile" 32 .

27 Freire (1831). No es posible aludir a este juicio sin subrayar la nobleza con que Ramón Freire, ex Director Supremo de Chile, actuó en él. De la lectura del expediente aparece que su disposición a restituir Cuchacucha a los Urrejola fue decisiva para que la Corte de Apelaciones fallara como falló. La lectura de la carta de Freire que consta a f. 1 del expediente es tan ilustrativa como conmovedora, y nos permitiremos reproducirla: "Sr. Don Juan de Dios Rivera / Santiago, 2 de septiembre de 1824. / Amigo y señor de mi estimación: / No puedo mirar con indiferencia el estado lamentable en que se hallan los que pueden decir derecho a la hacienda de Cuchacucha, que el anterior gobierno me dio en compensación de los que se me debían por diferentes acciones que tenía contra los intereses del Estado. / Tampoco [permite] mi delicadeza que aquellas personas crean que mis respetos pueden contenerlos para sus reclamos. Jamás he apetecido otra cosa que lo que es justo, y poseer lo que legítimamente me corresponda. Partiendo de esos principios, puede usted hacerlo entender así a las señoras Urrejola para que procedan seguras de que tendré la mayor satisfacción de que alcancen de los tribunales de Justicia lo que exija la equidad, y derechos con que se hallen. / Reitero a V. las pruebas de mi cordial amistad, y afectuosa estimación con que soy su atento amigo y servidor. / Ramón Freire".

28 Freire finalmente obtuvo una indemnización por ley de 24 de septiembre de 1845 , en Boletín de Leyes y de Decretos del Gobierno, XIII (1845), p. 106: "Sin embargo de lo declarado por la Suprema Corte de Justicia en su sentencia de 2 de mayo de 1843, en atención a los servicios prestados en la guerra de la independencia por el Capitán General don Ramón Freire, se autoriza al Presidente de la República para que, a los plazos que creyere conveniente, pague en dinero sonante al expresado Capitán General la cantidad de veinte mil setecientos cincuenta pesos que por dicha sentencia se mandó reconocer a favor suyo en la deuda interior". La sentencia aludida es Freire (1843).

29 Sesiones de los Cuerpos Legislativos de la República de Chile t. XIX, p. 433.

30 De acuerdo al propio Presidente Prieto, su intención con este oficio era llamar la atención de las cámaras legislativas sobre este tema, y no asumir personalmente la iniciativa de la tramitación de un proyecto de ley: ver Sesiones de los Cuerpos Legislativos de la República de Chile, t. XIX, p. 434.

31 Ver Sesiones de los Cuerpos Legislativos de la República de Chile, t. XIX: 434.

32 Ver Sesiones de los Cuerpos Legislativos de la República de Chile, t. XIX: 434. 
Finalmente, el Presidente Prieto parece haber estimado que una modificación del procedimiento establecido por el Senadoconsulto de 1821 no satisfacía parámetros institucionales mínimos, pues la reparación dispuesta por sus normas -como hemos visto supra- aparecía como un favor otorgado por el Gobierno y no como un acto de justicia ${ }^{33}$. Ello aparece ex post del discurso anual dirigido a las Cámaras Legislativas en 1834 por el Presidente de la República: "no he querido... hacer uso de una facultad cuyos actos pudieran parecer determinados por mi solo albedrío o consultados con la parcialidad, debiendo ser por su naturaleza aplicaciones rigorosas de la justa norma que estableciere la ley, y no providencias de excepción y de gracia" 34 .

Por consiguiente, al no compartir en el fondo la naturaleza del mecanismo previsto por el Senadoconsulto de 1821, y no habiendo constatado en la forma un interés activo de las Cámaras en solucionar el asunto de los secuestros, el Presidente Prieto optó por impulsar personalmente otra vía: asumir los criterios básicos de la reparación de los daños por secuestros en el marco de una nueva ley que rigiera el problema de la deuda interior.

\section{b. LA ETAPA INTERMEDIA}

En la sesión de la Cámara de Senadores del 18 de junio de 1834 se dio cuenta "de un oficio del Presidente de la República, quien pide se dicte una ley sobre arreglo y reconocimiento de la deuda interior" 35 , cuya tramitación efectiva no se daría sino hasta el 12 de junio del año siguiente, fecha en la cual se anunció el Mensaje del proyecto de ley, expedido por Prieto ${ }^{36}$. En este, el Presidente de la República subrayó que sobre la aprobación de dicho proyecto descansaban "el honor, la justicia y la prosperidad de la Nación" 37.

En lo concerniente a los secuestros, el proyecto original de Prieto fue, en esencia, el que aprobaría finalmente el Congreso. Sin embargo, el texto primitivo presentó una peculiaridad lingüística: la presencia del vocablo confiscaciones, que admitía abiertamente que durante el proceso de Emancipación habían existido prácticas derechamente privativas de dominio $^{38}$; por ello, tal denominación había sido evitada, en la medida de lo posible, en los textos normativos de los años de la Patria Nueva.

\footnotetext{
$33 \mathrm{Y}$ ello en circunstancias que los tribunales de justicia ya estaban aplicando la equidad para restituir bienes que habían sido secuestrados a realistas. Véase, en este sentido, Pozo (1833), en que en la vista fiscal (f. 25) se expresa que no debe perjudicarse a los herederos de un prófugo con el secuestro de una casa: "con razón no debía devolverse el sitio de la Cañada al doctor Pozo, porque siendo un realista voluntariamente emigró para irnos a traer la guerra y desolación; mas no fueron así sus herederos, y a quienes debe considerarse ahora mucho más decididos por la independencia, faltando ese respeto que no podría haberlos seducido".

34 Discurso del Presidente de la República a las Cámaras Legislativas, de 5 de junio de 1834, en Sesiones de los Cuerpos Legislativos de la República de Chile, t. XXIII, p. 24.

35 Sesiones de los Cuerpos Legislativos de la República de Chile, t. XXIII, p. 52.

36 Sesiones de los Cuerpos Legislativos de la República de Chile, t. XXIII, p. 332.

37 Sesiones de los Cuerpos Legislativos de la República de Chile, t. XXIII, p. 333.

38 Así, por ejemplo, el numeral 18 de su artículo primero reconocía como deuda nacional interior "las sumas que ingresaron al Tesoro Nacional a título de confiscaciones, secuestros o embargos decretados por el Gobierno republicano, tanto sobre bienes pertenecientes a individuos domiciliados en Chile como sobre propiedades de súbditos de la España o de potencias neutrales”. Sesiones de los Cuerpos Legislativos de la República de Chile, t. XXIII, p. 334.
} 
Rápidamente, el 17 de junio de 1835, se daría cuenta de un dictamen emitido por las Comisiones reunidas de Legislación y Hacienda del Senado sobre el proyecto, en términos particularmente laudatorios: ellas no podían "dispensarse de recomendar a la Cámara la necesidad y conveniencia de esta medida”, en razón de que el texto presentado "reúne los únicos principios equitativos y justos que en nuestras circunstancias puedan consultarse para conseguir tan interesante objeto". Sin perjuicio de lo anterior, el dictamen indicaba también la necesidad de introducir ciertas modificaciones y adjunciones ${ }^{39}$. El proyecto fue aprobado en general por la Cámara de Senadores el 19 de junio de $1835^{40}$.

Las sesiones inmediatamente sucesivas no contemplaron discusiones específicas sobre las disposiciones relativas a los secuestros. Sí aparece de ellas, sin embargo, la preocupación de Mariano Egaña respecto de la factibilidad del reconocimiento íntegro de la deuda interior, que se cristalizó el 3 de julio en un voto que pedía suspender la tramitación del proyecto hasta que el Gobierno detallara el monto al que ascendería la deuda.

La propuesta de M. Egaña fue desechada; sin embargo, conocemos el tenor del voto porque el autor solicitó su inserción en el acta de la sesión, y es el que sigue: "El Senado ha acordado que, para continuar en la discusión del proyecto de ley sobre reconocimiento de una deuda nacional interior, se le presente una razón del monto a que asciende cada uno de los veintitrés ramos de deuda parcial que conforme al citado proyecto deben constituir el total de esta deuda interior, sacándose dicha razón de los libros o documentos que precisamente deben existir en las oficinas de Hacienda" ${ }^{41}$.

De dicho voto, y de la aislada negativa de M. Egaña a aprobar varias disposiciones del proyecto ${ }^{42}$ o de postergaciones solicitadas por él durante la tramitación ${ }^{43}$, aparecen claramente sus temores acerca del peligro de ocasionar, con un proyecto bienintencionado, un ingente daño financiero a la aún precaria República ${ }^{44}$.

39 Sesiones de los Cuerpos Legislativos de la República de Chile, t. XXIII, p. 342.

40 Sesiones de los Cuerpos Legislativos de la República de Chile, t. XXIII, p. 335.

${ }^{41}$ Sesiones de los Cuerpos Legislativos de la República de Chile t. XXIII, p. 350.

${ }^{42}$ V. gr., en la referida sesión del 3 de julio, Egaña votó por la negativa respecto del artículo $1^{\circ}$, numeral $1^{\circ}$; en la del 15 de julio, respecto del artículo $1^{\circ}$ numeral 3o (ibíd., p. 363); en la de 12 de agosto, respecto del artículo $11^{\circ}$ numeral 11 (ibíd., p. 398; con una indicación, desechada, del siguiente tenor: "solo podrá empezarse a cubrir conforme al espíritu y letra de dichos decretos, cuando lo permitan las circunstancias de desahogo en que se hallare el Erario, y lo determinare una ley especial").

43 Sesión del 5 de agosto, respecto del artículo $1^{\circ}$ numeral 11 (ibíd., p. 393).

${ }_{44}$ De algunas indicaciones aparece incluso un celo patriota con un aroma revanchista contra quienes habían apoyado la causa realista. Por ejemplo, en la sesión del 3 de agosto, respecto del artículo $1^{\circ}$ numeral 10 (ibíd., p. 390), Egaña sugirió un texto alternativo al propuesto por el Ejecutivo respecto de depósitos de ciudadanos de la República que hubieren entrado al Erario de Chile por decretos del Gobierno español. Mientras el texto original no contemplaba ninguna condición especial para el pago de la deuda, Egaña sugirió insertar la siguiente: "siempre que se hiciese constar que pertenecían a individuos patriotas y que se trasladaron al Erario en odio de su adhesión a la causa de la Independencia" (el destacado es nuestro). En otras palabras, la restitución no se derivaba simplemente de la retención injusta por parte del Estado de una suma perteneciente a otro, sino que en razón de recompensa al individuo que hubiese mostrado fidelidad con la causa independentista. La indicación, totalmente ajena al espíritu del proyecto de superar los enconos de antaño, fue desechada por los restantes senadores. 
Los numerales que designaban a los secuestros fueron aprobados por la Cámara de Senadores en discusión particular durante las sesiones del $21^{45}$ y del $26^{46}$ de agosto, con ligeras modificaciones respecto del proyecto presentado por el Ejecutivo ${ }^{47}$. El 14 de septiembre se dispuso que el proyecto pasara a la Cámara de Diputados ${ }^{48}$, cuya tramitación muestra -a través del informe de su Comisión de Hacienda- que el propósito de la ley era propiamente reparatorio, a través de expresiones particularmente finas y lúcidas: "El noble sentimiento del patriotismo no puede ser compatible con el deseo de ver a la Nación comprometida con millares de acreedores cuyas esperanzas y derechos burlados hasta el día, los convierten si no en enemigos de la Patria en depresores de su reputación. Tampoco el patriotismo puede aconsejar la deshonra de negar las obligaciones contraídas ni la injusticia de privar para siempre de sus propiedades a los legítimos acreedores de la Nación”9

La Cámara de Diputados despachó el proyecto, con algunas modificaciones y añadiduras, el 16 de octubre ${ }^{50}$, y retornó a la Cámara de Senadores, que la aprobó sin otras alteraciones al día siguiente ${ }^{51}$. El Presidente Prieto promulgó su texto definitivo el 17 de noviembre de $1835^{52}$. A fin de cernir el alcance de la ley de reconocimiento de la deuda interior sobre los secuestros de bienes, conviene revisar los artículos pertinentes.

En primer lugar, el artículo $1^{\circ}$ desarrolló, en los cuatro numerales corrientes desde el 19 al 23, distintos problemas asociados al tema de los secuestros.

"Art. 1. La República reconoce como deuda nacional interior (...)

19. Las sumas que ingresaron al tesoro nacional a título de secuestros, o embargos decretados por el Gobierno republicano, tanto sobre bienes pertenecientes a individuos domiciliados en Chile, como sobre propiedades de súbditos de la España o de potencias neutrales.

20. Las cantidades procedentes de embargos o secuestros hechos por el Gobierno español, durante el período de su dominación, en bienes que pertenecían a ciudadanos de Chile.

\footnotetext{
45 Sesiones de los Cuerpos Legislativos de la República de Chile, t. XXIII, p. 407.

46 Sesiones de los Cuerpos Legislativos de la República de Chile, t. XXIII, p. 409.

47 En el numeral 19 (anteriormente 18), se suprimió la palabra "confiscaciones"; en el numeral 21 (anteriormente 20), se suprimió la palabra "confiscaciones” y se la reemplazó por "depósitos, embargos”. El cambio más notable se dio en el numeral 20 (anteriormente 19), en el que por una parte se cambió la palabra "chilenos" por la fórmula "de Chile", y -en especial- que al reglar las consecuencia asociadas a las privaciones de bienes originadas por autoridades españolas, el Senado no eliminó la palabra confiscaciones que sí eliminó en todos los otros casos, en que apuntaba a autoridades patriotas. Salvo que se tratase de una prodigiosa coincidencia, la diferenciación hecha entre las unas y las otras refleja cándidamente la visceral animadversión que aún subsistía en individuos ilustrados que además configuraban un texto que pretendía superar -en su vertiente patrimonial- la fractura originada por la Emancipación. La Cámara de Diputados, al revisar el proyecto, habría de suprimir la superviviente palabra "confiscación” del numeral 20 en su sesión de 14 de septiembre: Sesiones de los Cuerpos Legislativos de la República de Chile, t. XXIV, p. 192.

48 Sesiones de los Cuerpos Legislativos de la República de Chile, t. XXIII, p. 440.

49 Sesiones de los Cuerpos Legislativos de la República de Chile, t. XXIV, p. 170.

50 Sesiones de los Cuerpos Legislativos de la República de Chile, t. XXIV.

51 Sesiones de los Cuerpos Legislativos de la República de Chile, t. XXIII, p. 640.

52 Boletín de Leyes y de Decretos del Gobierno, VI (junio de 1834 - noviembre de 1835), p. 219.
} 
21. La parte que hubiese entrado en el tesoro de la República después de la restauración del país, como resto de los depósitos, embargos y secuestros decretados desde 1814 hasta 1817 por el referido gobierno español sobre propiedades extranjeras.

22. Los capitales que percibió el fisco por subasta o venta de propiedades secuestradas restituidas después a sus antiguos dueños en virtud de decretos del Gobierno, o de sentencias judiciales.

23. El valor de las donaciones hechas por los gobiernos republicanos con autorización conferida por el cuerpo legislativo sobre bienes secuestrados, a título de recompensa por servicios prestados a la Nación, en el caso de que dichos bienes hubiesen sido posteriormente devueltos a sus primeros propietarios".

Se advierte en estos cinco numerales dos grupos principales de cuestiones.

Primeramente, el de las víctimas originarias de secuestros, es decir, la reparación prevista respecto de aquellos sujetos cuya propiedad les había sido directamente privada por el gobierno: así, el numeral 19 reconoce como deuda el monto de todo secuestro o embargo efectuado por las autoridades independientes; el numeral 20 reconoce aquel correspondiente a los secuestros o embargos efectuados durante la restauración monárquica, mas solo respecto de las víctimas chilenas; y el numeral 21, el caso muy específico de los extranjeros que hubieran recibido una orden emanada de autoridades españolas con el objeto de privarles de algún bien, pero cuyo pago se hubiere cumplido una vez instalado el gobierno patrio.

Y segundamente, el de las víctimas derivadas de secuestros, es decir, el de aquellos sujetos que, habiendo recibido del Gobierno un bien previamente secuestrado, se vieron en la posterior obligación de restituirlo: el numeral 22 trata del caso de los bienes secuestrados que fueron adquiridos a título oneroso por un tercero - subasta o venta- que posteriormente, por orden de autoridad administrativa o judicial, se lo había restituido al sujeto del cual el Gobierno originalmente lo había secuestrado; y el numeral 23, el de los bienes secuestrados que fueron adquiridos a título gratuito por algún sujeto en reconocimiento de los servicios prestados a Chile. En ambos casos la privación también se entiende injusta; en el primero, porque el adquirente sufrió un detrimento al verse privado de un bien por el que había pagado; y en el segundo, porque aun restituido el bien a su propietario original, la causa de gratitud expresada por la Nación no se había extinguido y debía ser cumplida por otra vía, equivalente a la suma del bien en cuestión.

Es patente que los órganos legislativos se esmeraron en configurar un régimen de reparación de amplio espectro. Desde el punto de vista político, no deja de ser llamativo el hecho de que un gobierno republicano se hiciera cargo de actuaciones dañosas cometidas por las autoridades coloniales; ello puede $-\mathrm{y}$ debería - ser considerado como una poderosa manifestación de la continuidad de Chile en el tránsito del régimen colonial al independiente.

Comoquiera que sea, a más de la caracterización de los tipos de deudas que serían reconocidas, el régimen configurado a partir de la ley de 1835 para la devolución de sumas derivadas de secuestros quedaría marcado por dos importantes características: la condicionalidad de su entrada en vigor (i) y la aparición -al menos preliminar- de un plazo tras el cual no pudieran impetrarse las acciones correspondientes (ii). 
i. La condicionalidad de la entrada en vigor del régimen de reparación

El artículo $4^{\circ}$ de la ley de la Deuda Interior prescribía que "el reconocimiento de los créditos que procedan de embargos o secuestros, se arreglará a la ley que sobre la materia debe dar el Congreso nacional”.

Así, se daría un régimen normativo articulado por dos leyes: una -la ley de Deuda Interior- que permitía considerar los créditos procedentes de secuestros como parte de la deuda interior, y otra -específica de secuestros- que ejecutaría lo dispuesto por la primera, habilitando al cobro de las sumas respectivas. Como bien puede intuirse, el riesgo de tal remisión era que las autoridades entendieran que cualquier petición relativa a estas reparaciones se mantendría suspensa hasta la dictación de la segunda ley.

Y así fue, tanto por vía judicial ${ }^{53}$ como administrativa ${ }^{54}$. De hecho, esta técnica de suspensión había sido anticipada en 1828 , por vía judicial, a través de una sentencia en que la Corte Suprema negó la devolución de los bienes secuestrados hasta que se suscribiese un tratado que rigiera esta materia entre Chile y España ${ }^{55}$.

El pago de los créditos por secuestros quedaría suspenso, entonces, hasta una fecha indefinida ${ }^{56}$, lo que originó una creciente tensión entre la Corona española y el gobierno patrio. En efecto, este tema permaneció en primer plano durante las negociaciones para el Tratado de Paz y Amistad entre Chile y España ${ }^{57}$. Ello aparece claramente de las inéditas actas del Consejo de Estado, que no solo dejaron constancia de evoluciones en la redacción del artículo del Tratado que reglaba los secuestros ${ }^{58}$, sino también de instrucciones en caso de que las negociaciones se entrabasen ${ }^{59}$.

El Tratado, suscrito el 25 de abril de 1844 , dispuso en su artículo $5^{\circ}$ lo siguiente:

\footnotetext{
53 Así puede constatarse de varias sentencias, que suspendieron cualquier reclamación hasta tal promulgación: Herederos de Chopitea (1845): "debe esperarse la promulgación de la ley a que aluden los artículos citados"; $\mathrm{Na}$ vajete (1848): "y que respecto al valor de los escombros de dicho sitio se espere la ley que se dicte en materia de secuestros".

54 V. gr., Decreto Supremo de 23 de noviembre de 1841, JS 1341 pieza 7, f. 2, incluso suspendiendo lo dispuesto por sentencia ejecutoriada.

55 Esta técnica de postergación a fecha incierta había sido anticipada por vía judicial: véase Vildósola (1828), en la que se negó la devolución de los bienes secuestrados "hasta que concluida la guerra se disponga por tratados entrambas Naciones [Chile y España] lo conveniente”.

56 No obstante, bajo el gobierno de Prieto se dictaron otros cuerpos normativos dirigidos a esclarecer la aplicación de la ley de 1835. El más importante fue una ley complementaria, de 2 de febrero de 1837 (Boletín de Leyes y de Decretos del Gobierno, VII [octubre de 1835 - diciembre de 1837], p. 67). El origen de esta ley fue una consulta del jefe de la comisión de cuentas al Ministro de Hacienda, que este decidió elevar al dictamen del Consejo de Estado, como se advierte en la sesión de 2 de marzo de 1836: Actas del Consejo de Estado (en adelante, Actas CE), vol. 3, f. 141 vta.

57 Aconteció así también respecto de otros Estados latinoamericanos: véase CÁRdenAs GueUdinOt (1998) pp. 270-275.

58 Cfr. con el texto definitivo, la primera versión en Actas del Consejo de Estado de la República de Chile, volumen 5, f. 52, sesión de 8 de octubre de 1842.

59 Sesión de 27 de octubre de 1842, en Actas del Consejo de Estado de la República de Chile, volumen 5, f. 58, al margen: "(b) Si por el Gobierno Español se exigiere alguna seguridad de que sus súbditos no serían tratados menos favorablemente que los ciudadanos chilenos relativamente a este punto, se añadirá a este artículo lo siguiente: 'La República de Chile se compromete a que en este arreglo no se hará diferencia alguna entre los ciudadanos chilenos y los súbditos españoles'”.
} 
"Art. 5. El reconocimiento de los créditos que procedan de embargos o secuestros hechos en Chile se fijará en una ley de consolidación de estos mismos créditos que dará el Congreso Nacional de esta República según lo prometido en el art. $4^{\circ}$ de la ley de deuda interior de la misma; y su Majestad Católica se obliga a hacer igual reconocimiento y arreglo respecto de los créditos de la misma especie que pertenezcan a ciudadanos chilenos en España"60.

La suspensión del cobro de los créditos derivados de secuestros no significó que no se pudieran ventilar otras cuestiones referidas a los secuestros de bienes: ello era perfectamente posible. El mejor ejemplo de esta bifurcación está dado por una sentencia Navajete de 1848, en la que la Corte Suprema, por una parte, declaró que un sitio secuestrado era de propiedad de los particulares demandantes, y por otra, suspendió el cobro de un crédito por el valor de los escombros de la casa que se hallaba en el referido sitio $^{61}$ : lo primero no era un crédito, mientras que lo segundo - una indemnización- sí lo era. Análogamente, la judicatura no tuvo impedimento en otros pleitos para examinar la validez de un remate, alzando los secuestros de ser el remate nulo ${ }^{62}$, o declarando la propiedad del tercero adquirente en caso de haber sido válido $^{63}$; o incluso para revisar si ciertos bienes efectivamente habían entrado al Erario ${ }^{64}$.

ii. El establecimiento preliminar de un dies ad quem para impetrar las acciones relacionadas con la reparación de secuestros

En el artículo 14 de la ley de 1835 se estableció lo siguiente: "será necesario que los expedientes de esta naturaleza ${ }^{65}$ se principien dentro de los plazos que designa el artículo $8^{\circ}$ ": seis meses para acreedores que morasen en el territorio de la República, un año para los residentes en América, y un año y medio para quienes residiesen en cualquiera otra parte. Por consiguiente, transcurridos estos plazos se haría imposible la impetración de cualquier acción. Desde este momento devendría límpido que la intención del legislador era cerrar definitivamente el problema de los secuestros, aun cuando quedara suspensa su solución en razón de lo expresado en el punto (i) anterior.

Sin embargo, la remisión antedicha fue torpemente articulada. El artículo $8^{\circ}$ establecía los plazos "en caso de haber perdido un acreedor fiscal los comprobantes de su crédito", por lo que, de acuerdo al tenor literal de la ley, los acreedores que hubieran mantenido en su poder los comprobantes respectivos podrían haber evitado la norma de vencimiento y haber pedido a perpetuidad el reconocimiento de los créditos correspondientes.

No hubo de sorprender que el 14 de febrero de 1837 el gobierno dictara un decreto ley que simplificase el tratamiento de los plazos, reiterando en su artículo $1^{\circ}$ los que habían sido indicados en el artículo $8^{\circ}$ de la ley de 1835, pero sin reintroducir la distinción acer-

${ }^{60}$ Aprobado por el CE el 30 de octubre de 1844: véase Actas del Consejo de Estado de la República de Chile, volumen 5 , f. 186 vta.

${ }^{61}$ Navajete (1848).

62 Villaurrutia (1838).

${ }^{63}$ Beltrán (1847).

${ }^{64}$ García (1840).

${ }^{65}$ Es decir, "cobranzas contra el Fisco", en coordinación con el artículo 13 de la ley. 
ca de si el acreedor había o no perdido su comprobante ${ }^{66}$. Empero, esta simplificación no alcanzó a tocar el problema de los secuestros, pues el artículo $4^{\circ}$ prescribió explícitamente que "esta disposición no comprende los créditos procedentes de embargos o secuestros, para cuyo reconocimiento debe esperarse la ley especial a que se refiere el artículo $4^{\circ}$ de la ley de 17 de noviembre de 1835 ".

La suspensión del régimen de reconocimiento de créditos por secuestros era, al fin, total, pues por el mentado artículo este decreto ley terminó también asignándole a la futura ley de secuestros la determinación del plazo tras el cual no sería posible reclamar las reparaciones respectivas, prefigurado en principio por la ley de 1835.

\section{LA SOLUCIÓN DECISIVA: LA LEY DE SECUESTROS, DE 15 DE SEPTIEMBRE DE 1853}

La última etapa de la superación del entuerto al que habían expuesto al Estado de Chile las autoridades políticas de las décadas de 1810 y 1820 se materializó con la entrada en vigor de la llamada Ley de Secuestros. Esta fase se caracterizó por la asunción de un criterio reparatorio plenamente operativo en el régimen de la responsabilidad, materializado a través de un estrato propiamente normativo (a) y uno referido a su concreción jurisprudencial (b).

\section{a) El ESTRATO NORMATIVO}

Solo al final del gobierno del Presidente Bulnes se daría impulso a la tan anunciada Ley de Secuestros: el 14 de agosto de 1850 fue presentada al Senado ${ }^{67}$, que la discutió velozmente ${ }^{68}$, despachándola a la Cámara de Diputados el 21 de agosto ${ }^{69}$. Luego de quedar empantanada su tramitación por los trastornos que precedieron a la elección presidencial de Manuel Montt y por inconvenientes ministeriales internos ${ }^{70}$, la Cámara de Diputados revisó y discutió minuciosamente su texto a partir del 9 de julio de $1852^{71}$, cuyas modificaciones fueron aprobadas por el Senado el 5 de septiembre de $1853^{72}$.

Finalmente, la Ley de Secuestros fue promulgada el 15 de septiembre de $1853^{73}$; es decir, más de treinta y cinco años después del inicio de la Patria Nueva, que fue el período de mayor incandescencia en el secuestro de bienes. No se trata de un documento de gran extensión, pero sí se advierte en él un rigor particular en esclarecer tan prolijamente como

\footnotetext{
${ }^{66}$ Boletín de Leyes y de Decretos del Gobierno, VII [octubre de 1835 - diciembre de 1837], p. 102. Posteriormente se abrió un nuevo término de seis meses, en virtud de un decreto de 3 de abril de 1839 (Boletín de Leyes y de Decretos del Gobierno, VIII [1838-1839], p. 131), atendiéndose a "motivos justos", según lo expresado en el preámbulo de dicho decreto.

67 Sesiones del Congreso Nacional (en adelante, SCN) de 1850, p. 314.

68 Sesiones del Congreso Nacional de 1850, pp. 340 y 341.

69 Sesiones del Congreso Nacional de 1850, p. 344.

70 Véase en especial la carta de Antonio Varas al Encargado de Negocios de España, de 30 de junio de 1852. En Discursos de apertura en las Sesiones del Congreso y Memorias Ministeriales. Tomo IV. Imprenta del Ferrocarril. Santiago. 1858, p. 291.

71 Sesiones del Congreso Nacional de 1852, pp. 144-150.

72 Sesiones del Congreso Nacional de 1853, pp. 229-230.

73 Boletín de Leyes y de Decretos del Gobierno, XXI [1853], p. 470.
} 
fuera posible los diversos aspectos allí tratados. Examinaremos los que aparecen como fundamentales para comprender la magnitud de la mutación legislativa ${ }^{74}$.

En primer lugar, del artículo $1^{\circ}$ aparece que la Ley estableció un mecanismo de consolidación: es decir, ella reconocía que los créditos derivados de secuestros ya existían, pero precaria o provisionalmente, y que adquirirían un carácter definitivo cumpliéndose con lo dispuesto en sus disposiciones:

"Art. 1 ${ }^{\circ}$ Procédase a la consolidación de las sumas que ingresaron al Tesoro a título de secuestros o embargos, en los casos, modo y forma que se expresan en los artículos siguientes" 75 .

En segundo lugar, la consolidación de la deuda por secuestros no fue concebida por la ley como una gestión administrativa, sino como un asunto jurisdiccional; con ello se satisfacía el anhelo del Presidente Prieto de contar con una institucionalidad que representara el carácter propiamente reparatorio de la medida, y no como una gracia especial de naturaleza política. El artículo 10 disponía lo siguiente:

"Art. 10. Ningún Juzgado admitirá reclamaciones sobre deudas fiscales procedentes de secuestros, que expresa o tácitamente se hallen excluidos del reconocimiento por la presente ley".

No obstante, esta disposición tenía un objetivo político más discreto e influyente y que no sobresale a simple vista en nuestros días: impedir cualquier pretensión de la Corona española para sustraer las materias de secuestros de los tribunales chilenos, otorgándole su conocimiento a tribunales arbitrales internacionales. Los antecedentes con que contamos sobre este aspecto muestran que el arbitraje era un riesgo cierto ${ }^{76}$.

74 Se trató efectivamente de una mutación, y no de una articulación con el régimen del Senadoconsulto de 1821. Aun no conteniendo ninguna disposición que expresara la derogación de este, la Corte Suprema fue inequívoca en entender que con la ley de 1853 se abría un nuevo régimen de reparación de las deudas por secuestros, excluyente del anterior. En este sentido, consúltese Herederos de Urrejola (1853), en la que, habiendo entrado en vigor la ley de 1853 después de emitida la sentencia de primera instancia y durante la tramitación ante la Suprema Corte, esta dispuso lo siguiente: "suspéndanse los efectos de la sentencia apelada de f. 42, y devuélvanse los autos a los interesados para que hagan las gestiones que vieren convenirles con arreglo a la Ley de 15 de septiembre del presente año".

75 La simplicidad de esta disposición fue producto de las modificaciones introducidas por la Cámara de Diputados a su respecto. El texto original prescribía una serie de remisiones a las normas que habían precedido a la Ley de Secuestros en esta materia: "Art. 1 ${ }^{\circ}$. Procédase a la consolidación de las sumas que ingresaron al tesoro a título de secuestros o embargos en el modo y forma que previenen la ley de 17 de noviembre de 1835 , el decreto de 22 de febrero de 837, desde el artículo 50 hasta el art. 11 inclusive y el de 11 de marzo del mismo año" (Sesiones del Congreso Nacional de 1852, p. 147). Con razón esta redacción fue entonces calificada por el diputado Reyes como "demasiado compleja”.

${ }^{76}$ La elegante crispación política que suscitó este punto aparece de la correspondencia oficial entre Chile y España. De acuerdo al Encargado de Negocios español, la Ley de Secuestros era "un mero reglamento para hacer efectivo lo estipulado y previsto en el Tratado" (carta de 12 de junio de 1851, en Discursos de apertura, cit., p. 290), puntualizando que "es justo que Chile se inhiba en la ley de conocer exclusivamente por sus tribunales de la averiguación contenciosa de los créditos mandados consolidar (...) Un tribunal mixto de jueces árbitros 
Por su parte, el artículo 12 estableció una radicación forzosa, pues en caso de que se hubiera seguido gestiones inconclusas ante otras autoridades para la consolidación de las deudas, ellas debían pasar a conocerse por los tribunales ordinarios. Y, aún más sorprendentemente, este mismo artículo preveía la posibilidad de que ciertas reclamaciones "nuevamente pudieran entablarse y sujetarse a pleitos":

"Art. 12. Las reclamaciones que estuvieren pendientes o las que nuevamente pudieran entablarse y sujetarse a pleitos, serán ventiladas ante los juzgados ordinarios, debiendo comprobarse la legitimidad del derecho con documentos fehacientes".

Por supuesto, la ley no podía establecer una afectación de la cosa juzgada; lo que probablemente reconocía era la precariedad de las decisiones administrativas que hubiesen resuelto asuntos sobre secuestros, las que podían ser reexaminadas por vía jurisdiccional.

Y en tercer lugar, la Ley de Secuestros fijaba un plazo de prescripción de la acción para exigir el pago de la deuda:

"Art. 13. Los individuos que se creyeren con derecho a cobrar las cantidades o bienes secuestrados, presentarán sus reclamos o establecerán sus gestiones en el término de cuatro años, contados desde la promulgación de la presente ley, transcurridos los cuales no se admitirá reclamación alguna”.

Esta disposición no hizo más que ejecutar el artículo 6º del Tratado de 1844 entre Chile y España, que había dispuesto por primera vez el plazo de cuatro años para hacer valer los correspondientes créditos:

"Art. 6. Los ciudadanos chilenos o súbditos españoles, ya se hallen establecidos en las provincias de ultramar o en otra parte, que a virtud de lo dispuesto en los dos artículos anteriores tengan alguna reclamación de bienes que hacer ante uno $u$ otro gobierno, la presentarán en el término de cuatro años contados desde el día de la ratificación del presente Tratado, acompañando una relación sucinta de los hechos apoyada en documentos fehacientes que justifiquen la legitimidad de la demanda. Bien entendido que determinados dichos cuatro años no se admitirán nuevas reclamaciones de esta clase bajo pretexto alguno.

Sin embargo, si la ley a que se refiere el artículo $5^{\circ}$ no se hubiere promulgado, antes de la ratificación del presente Tratado, el dicho plazo de cuatro años, relativamente a los créditos de que se trata en el expresado artículo, principiará a correr desde la fecha de la promulgación de la ley. Y las reclamaciones que se hagan en la forma que

nombrados por Chile y España, sería el que debiese fallar tales controversias. Chile ha seguido ya este medio en su Tratado con Inglaterra de 19 de enero de 1839” (ibid.). Luego de una intensa correspondencia, el Encargado de Negocios de España terminaría cediendo al respecto frente a Chile, con dignísimas expresiones contenidas en su carta de 8 de agosto de 1853: "es tan alta la confianza que el Gobierno de S. M. Católica abriga en la justificación de la Magistratura chilena, que no temería comprometer el interés de sus nacionales, renunciando a la garantía del Tribunal mixto" (ibid., p. 306). 
prescribe este artículo, antes de la promulgación de la ley y después de ratificado el Tratado, se considerarán hechas dentro del plazo establecido”.

Por consiguiente, el plazo para interponer las demandas que perseguían la consolidación de las deudas por secuestros habría de vencer el 15 de septiembre de 1857. Como bien puede imaginarse, algunos de estos juicios, deducidos en tiempo y forma, se dilataron hasta entrada la década de $1860^{77}$.

Chile ya contaba con el instrumento que permitiría reparar, aun parcialmente, el enorme daño patrimonial ocasionado por las tempestades políticas de la Emancipación. Ya era claro que la injusticia había existido, que era de gran magnitud y que debía ser reparada. Y ya incluso se criticaba la designación eufemística de "secuestros". El diputado Alejandro Reyes, en plena discusión de la ley de 1853, señaló con tanta vehemencia como elegancia: "No entraré en la cuestión de si los secuestros han sido robo o no. Lo único que sé es que en los libros de las oficinas públicas consta que 506.000 pesos es la cantidad que aparece secuestrada, y todo el mundo sabe que ascendió a más de 3 millones. Por consiguiente, si lo primero fue tomado por represalias, lo segundo no merece otro nombre que el de robo" 78 . Aun pudiendo dudarse la exactitud en la tipicidad del delito invocado, esta alocución apuntaba directamente al fondo del problema que la ley de 1853 procuró solucionar, o al menos mitigar.

\section{b) EL ESTRATO JURISPRUDENCIAL}

Al encomendársele la solución concreta de las cuestiones relativas a los secuestros de bienes según la ley de 1853, la judicatura nacional no se vio enfrentada a una tarea sencilla. Del examen de sus sentencias, concentradas en muy pocos años, subyace la tensión de reconocerse como una pieza clave en la superación definitiva de la herida más traumática subsistente en la naciente República: el Tratado firmado en 1844 entre Chile y España no hubiera sido honrado por Chile si los mecanismos internos de solución se hubieran presentado como meramente nominales.

Así, los puntos de interés de estas sentencias pueden dividirse en dos grupos principales: primeramente, el tratamiento de los requisitos que hacían procedente la reparación según la Ley de Secuestros (i); y segundamente, la naturaleza de la reparación declarada procedente por los tribunales (ii).

\section{i. Los requisitos de la reparación}

La procedencia de la reparación de los secuestros perpetrados en la época de la Emancipación dependía, sin perjuicio de las características de cada especie, del cumplimiento de cuatro requisitos capitales: la existencia de un secuestro (1), el hecho de que este hubiera sido efectuado por autoridad competente (2), que el secuestro fuera debidamente probado (3), y por último que el secuestro no hubiera sido previamente indemnizado (4).

77 Cárdenas Gueudinot (1998) p. 286.

78 Sesiones del Congreso Nacional de 1852, p. 149. 
1. La existencia de un secuestro.

Como bien se ha señalado precedentemente, el artículo $1^{\circ}$ de la ley de 1853 daba lugar a la consolidación "de las sumas que ingresaron al tesoro a título de secuestros o embargos”. Esta dupla apuntaba a una realidad común, sin perjuicio de que la expresión "embargo" la describiese como potencialmente transitoria.

Aún más; salvo respecto de un caso específico ${ }^{79}$, la jurisprudencia de la época entendía que la denominación específica no era determinante para la procedencia de la indemnización, bastando que la situación coincidiera en el fondo con la naturaleza del secuestro. Un caso muy interesante en este sentido es Aguirre Solarte, de 1860. En este expediente, se ventiló el problema del apresamiento en Valparaíso de la fragata inglesa Lord Cathcart en octubre de 1820 en razón de que ella transportaba mercaderías pertenecientes a súbditos españoles desde Arica -a la sazón territorio de la Corona de Castilla- a Valparaíso. En 1822 se declaró buena presa el cargamento, disponiéndose al mismo tiempo la libertad de la embarcación. Entrada en vigor la ley de 1853, los representantes de Aguirre Solarte pidieron la consolidación de una suma considerable de dinero a los tribunales de justicia.

El juzgado de letras decidió que no había lugar a la consolidación de la suma, amparándose en el artículo 10 de la ley de secuestros, que establecía que "ningún juzgado admitirá reclamaciones sobre deudas fiscales procedentes de secuestros, que expresa o tácitamente se hallen excluidas del reconocimiento por la presente ley". En otras palabras, de acuerdo a este tribunal, un apresamiento no era un secuestro y por lo tanto no daba lugar a indemnización.

La Corte Suprema revocó la sentencia anterior, inclinándose hacia un criterio sustantivo más que de mera denominación del mecanismo de privación de dominio. En razón de lo anterior, dispuso que "si se declaró buena presa por la sentencia de la junta de hacienda, corriente a f. 111, cuaderno agregado, fue únicamente en consideración a ser propiedad de súbditos españoles, y por consiguiente, ha sido un verdadero secuestro". Dicho en otras palabras, toda privación del dominio fundada sobre motivos de enemistad política debía ser considerada como un secuestro, cualquiera hubiera sido el vocablo utilizado para calificarla, y por lo tanto daba lugar a la consolidación de la suma correspondiente ${ }^{80}$.

Solo un grupo de mecanismos de privación del dominio asomó como excepción a las restituciones e indemnizaciones derivadas de secuestros. Se trataba de las "pérdidas y perjuicios causados por requisiciones militares, prorratas, talas o saqueos mientras duraron la guerra de la independencia y las disensiones domésticas", que el artículo $2^{\circ}$ numeral $5^{\circ}$ de la ley de 1835 ordenaba no reconocer como deuda de la nación. Sería posible argüir que la excepción se justificaría por el hecho de que tales prácticas no obedecen necesariamente a una práctica de índole política; pero lo cierto es que el hecho de que no obedezcan necesariamente a tal finalidad no significa que en ciertos casos concretos sí puedan hacerlo. Hay entre los secuestros y las figuras de este numeral una molesta disrupción, que ocasionó problemas prácticos al menos en una sentencia: González, de 1857, en que el juez de letras estimó que las distintas partidas reclamadas por el actor no constaban "en ningún documento

\footnotetext{
79 Que se examinará al final de este numeral.

80 Aguirre Solarte (1860).
} 
fehaciente; y aun cuando estuviesen comprobadas deberían considerarse excluidas de la deuda nacional conforme a lo dispuesto en el inciso $5^{\circ}$ art. $2^{\circ}$ de la ley de 17 de noviembre de 1835". Dicha sentencia fue confirmada posteriormente por la Corte Suprema ${ }^{81}$.

2. El secuestro por autoridad competente

De acuerdo al artículo $3^{\circ}$ de la ley, la consolidación de sumas procedentes de embargos o secuestros requería que la privación de dominio hubiera sido hecha "por autoridad competente".

Cabe inquirir acerca de qué debe entenderse por tal. Sin duda, lo eran las autoridades patriotas que habían dispuesto la privación de bienes de realistas, como aparece de la mayor parte de las sentencias tratadas en este estudio. Pero podría haber dado lugar a debate el caso de las autoridades realistas que hubieran engendrado algún perjuicio a los patriotas, principalmente durante la Reconquista.

En efecto, desde una perspectiva meramente política, parecería sorprendente que el Estado de Chile se hubiera mostrado dispuesto a indemnizar solamente a los antiguos enemigos del régimen republicano, excluyendo del régimen de la ley de 1853 a los partidarios de este que habían padecido algún perjuicio de mano de las autoridades españolas. La respuesta a este punto, que se deriva de los numerales 20 y 21 del artículo $1^{\circ}$ de la ley de 1835, nos está confirmada por un par de sentencias.

En la sentencia Muñoz, de 1858, se ventila la cuestión de una propietaria rural que, tras la victoria de los realistas en Rancagua, había sufrido -según sus propios dichos- cuantiosas pérdidas por orden directa del general Mariano Osorio: arrasamiento de una finca, destrucción y saqueo de una casa, confiscación de ganado vacuno, ovejuno y caballar, entre otros desmanes. Sujetándose a la ley de 1853, demandó al Fisco la indemnización por todos estos perjuicios.

El juzgado de letras no dio lugar a ninguna de las indemnizaciones pedidas. Empero, resalta en su sentencia el hecho de que no rechazó de plano la demanda por el hecho de que los perjuicios habían sido obra de manos del ejército realista, sino que declaró que "que tampoco consta si fueron o no competentes las autoridades que ordenaron dichos secuestros, supuesta que fuese la efectividad de estos". En otras palabras, las autoridades españolas podían ser tenidas por competentes, siempre que tal competencia fuese probada.

En efecto, así lo entendió la Corte Suprema. No obstante haber confirmado la sentencia de primera instancia, le introdujo una muy importante declaración, motivada por la presentación ante ella de documentos adicionales, con los que la demandante logró probar que "don Juan Antonio Olate, comisionado del jefe del Gobierno Español, recibió doscientos cinco pesos cincuenta centavos de la enajenación del trigo secuestrado a don Rafael Eugenio Muñoz", declarándose por consiguiente "que deben reconocerse en la deuda interior de secuestros los doscientos cinco pesos cincuenta centavos de que se ha hecho mérito" 82 .

En el caso concreto, la indemnización resultó exigua contrastada con las pretensiones de la demandante; pero en el cuadro general resulta difícilmente discutible que los perjui-

81 González (1857).

82 Muñoz(1858). 
cios ocasionados por secuestros durante la llamada Reconquista se hallaban efectivamente cubiertos por las disposiciones de la ley de 1853.

Tal conclusión deviene ya palmaria a partir del examen de la sentencia Herederos de Villanueva, de 1857. En este expediente se examinó la cuestión del secuestro de un bergantín y de su cargamento, ordenado por el Presidente Marcó del Pont en 1816. Probado el secuestro, y probado el valor del buque y de las mercaderías, el juez de letras declaró derechamente la consolidación de la deuda, que fue confirmada por la Suprema Corte con la sola declaración de hallarse sujeto dicho haber a compensación con las sumas que le correspondía pagar al particular por derechos de internación de las mercaderías ${ }^{83}$.

\section{El secuestro probado}

La ley de 1853 establecía en su artículo $3^{\circ}$ que la consolidación de las sumas procedentes de secuestros o embargos "de que no hubiere constancia en las oficinas públicas" se verificaría "siempre que se pruebe con documentos fehacientes la efectividad del embargo o secuestro hecho por autoridad competente".

Como es de imaginarse, el problema probatorio fue uno de los más difíciles de superar para quienes se vieron afectados por estas exacciones: en 1853 ya habían transcurrido más de treinta años desde la aprehensión de los bienes, por lo que muchos de los documentos requeridos eran ya inubicables, o derechamente se hallaban destruidos.

Un primer elemento a probar era la mera efectividad del secuestro. Su prueba no era tan sencilla como aparenta a primera vista, pues ella involucraba probar varios elementos yuxtapuestos. En primer lugar, que la orden había emanado de autoridad competente; y en segundo lugar, que las sumas hubieran ingresado efectivamente al Erario público ${ }^{84}$.

Un segundo elemento a probar era el valor de las especies secuestradas. Aun probada la efectividad del secuestro, esta situación podía transformarse en un verdadero rompecabezas, tanto para el actor como también para el tribunal, como aparece manifiestamente de una sentencia Fernández Beltrán de 1856. En ella, si ya el valor de la chacra de Manquehue era incierto tanto al momento de la aprehensión de la finca como en el de la ejecución, la cuestión se seguiría complicando con vacas, otros ganados y enseres ${ }^{85}$.

Los vaivenes que bien pueden intuirse en la administración de estas pruebas en juicio estaban sujetos al factor adicional de que la ley, como ya hemos señalado, exigía la presencia de "documentos fehacientes". Este calificativo le permitía a la judicatura desechar demandas completas, como ocurrió en la primera instancia de la causa Muñoz, matizada posteriormente por la Corte Suprema sobre la base de documentos que le fueron presentados a ella de modo directo ${ }^{86}$.

\footnotetext{
${ }^{83}$ Herederos de Villanueva (1857).

84 González (1857). A falta de antecedentes de que la suma hubiera ingresado a arcas fiscales, la restitución era improcedente: véase Herederos de Chopitea (1854). Y en tercer lugar, como ya se ha referido a propósito del punto 1 anterior, no debía tratarse de uno de los casos previstos en el artículo $2^{\circ}$ numeral $5^{\circ}$ de la ley de deuda interior de 1835 .

85 Fernández Beltrán (1856).

86 Muñoz (1858).
} 
Sin embargo, el celo del legislador sobre la necesidad de contar con documentos que hicieran fe de las cuestiones que se agitaban era perfectamente comprensible, pues la falsificación de documentos concernientes a hechos a la sazón bastante antiguos era perfectamente posible. Una sentencia Vicuña de 1856 da cuenta de ello. Probada ante la Corte Suprema tal falsificación a través de un informe de peritos, ella revocó la sentencia de primera instancia, aun frente a la protesta de inocencia invocada por el actor ${ }^{87}$, cuyo objeto era probablemente el de impedir o mitigar las consecuencias establecidas en el artículo 14 de la ley de $1853^{88}$.

Como hemos visto, la ley no exigía prueba fehaciente de aquellos hechos que constaran de documentos preservados en las oficinas públicas. Sin embargo, era perfectamente posible que algunos funcionarios de la Administración se negaran a exhibir documentos potencialmente perjudiciales para los intereses fiscales. La Corte Suprema, en una casi invisible decisión que resulta valiosísima desde un punto de vista procesal, decidió que todo juez que conociera de este tipo de causas podía compeler a la Administración a entregar los documentos pertinentes ${ }^{89}$.

A más de lo anterior, es patente que los tribunales de justicia podían desplazar -y desplazaban- la carga de la prueba sobre el Fisco respecto de otros hechos. Por ejemplo, los pagos efectuados por este por cuenta del dueño durante el tiempo de duración del secuestro; estos, de no ser probados por el Fisco, no podían ser compensados en la liquidación ${ }^{90}$.

\section{El secuestro no previamente indemnizado}

El legislador de 1853 entendió que, transcurridas más de tres décadas desde la aprehensión de los bienes secuestrados, existía un riesgo cierto de que ciertos peticionarios -deshonestos o simplemente ignorantes- quisieran solicitar la consolidación de sumas que habían sido previamente indemnizadas bajo el imperio de la legislación precedente. A fin de evitar este enriquecimiento injusto, el artículo 11 de la ley imperaba que "para entablar nuevos expedientes de cobranza contra el Fisco, lo mismo que para seguir los que ya están principiados, será indispensable presentar un certificado de la Contaduría Mayor por el que conste que la cantidad demandada no ha sido satisfecha ni registrada en el libro de la deuda interior".

87 Vicuña (1856).

88 "Los acreedores que pretendiesen cobrar créditos ya satisfechos o con documentos falsos, serán penados a favor del Fisco con igual valor del crédito que intentaren hacer valer, o, en su defecto, con una prisión que no suba de dos años, ni baje de seis meses, sin perjuicio de perseguir criminalmente al falsificador. Quedarán exentos de esta pena, si justificasen la inocencia de sus procedimientos".

89 Abadía (1859). La redacción es discretísima y puede pasar fácilmente inadvertida. El considerando segundo del fallo de primera instancia señalaba que "a más del poderoso fundamento que el gobierno ha tenido para negar las copias pedidas, no es el juzgado quien podría compelerlo a darlos, sobreséase hasta que el reclamante presente los comprobantes de su acción". La sentencia de la Corte señaló lo siguiente: "Vistos: con exclusión de la última parte del segundo considerando, se confirma la sentencia apelada de 4 de junio último, entendiéndose el sobreseimiento hasta que sea resuelta la cuestión diplomática sobre que ha recaído la convención sancionada en 18 de octubre último". Como el dispositivo correspondía al sobreseimiento, la "última parte" del considerando era la subordinada "no es el juzgado quien podría compelerlo a darlos", de lo que se desprende que la Corte Suprema entendió que el juzgado sí podía ordenar la exhibición de los documentos respectivos.

90 Correa (1856). 
Este certificado se transformó en un requisito esencial de la tramitación, que no podía ser omitido ni tampoco sustituido mediante otros medios probatorios. Así aparece prístinamente de la sentencia Monreal de 1860, en la que los tribunales absolvieron al Fisco porque la recurrente se había "negado obstinadamente durante el curso de la causa a cumplir con este requisito", aun cuando de la misma sentencia aparece que el Ministro de la Tesorería principal de Concepción reconocía que los productos de la venta del predio secuestrado estaban en sus arcas. En síntesis, se trata de un caso manifiesto de preferencia procesal de la verdad formal por sobre la verdad material ${ }^{91}$.

En ocasiones, fue el propio legislador quien dispuso una indemnización por los perjuicios sufridos en razón de los secuestros. Es el caso de la familia Urrejola, que se vio beneficiada por una ley de 19 de junio de 1858 para avanzar en las indemnizaciones que les eran debidas, cuyo artículo único era el siguiente: "Devuélvase por gracia en dinero efectivo a los herederos de don Luis Urrejola los siete mil novecientos sesenta y ocho pesos, noventa y seis y medio centavos, que ha percibido el Fisco por arriendo de los fundos que les ha tenido secuestrados" $"$.

Atendida la existencia de dicha ley, cualquier indemnización posterior a ella que se refiriera a los arriendos de los mismos predios secuestrados se consideraría injusta, en razón de la existencia de un enriquecimiento ilícito. Así lo declaró la Corte Suprema en 1860, al haber perseverado los Urrejola contra el Fisco en una demanda de rebaja del canon de arrendamiento de la finca de Pomuyeto, en razón de no haber sido amparados aquel frente al despojo parcial de este predio que habían sufrido en 1847 por obra del dueño de uno colindante. La sentencia de primera instancia dio lugar a la rebaja pedida por los Urrejola. La Corte Suprema revocó la sentencia anterior, "considerando que por la ley de 19 de junio de 1858, se mandaron devolver a los herederos de don Luis Urrejola todas las cantidades que el fisco había percibido por el arriendo de los fundos que les tuvo secuestrado" "93. Así, indemnizados los Urrejola por la ley, no podían serlo nuevamente por sentencia judicial en virtud de los mismos hechos dañosos.

\section{ii. La naturaleza de la reparación}

Los expedientes en que se ventilaron causas de secuestros sobre la base de la ley de 1853 constituyeron, a pesar del tiempo transcurrido, un grupo jurisprudencial de dimensiones bastante considerables, y resulta notable que en muchas de estas causas los particulares afectados por los secuestros hayan resultado total o parcialmente victoriosos ${ }^{94}$. Ciertos elementos de las reparaciones con las que se vieron beneficiados merecen particular atención: los tipos de reparación (1), la determinación del valor de los bienes secuestrados

\footnotetext{
91 Monreal (1860).

92 Boletín de Leyes y de Decretos del Gobierno, XXVI [1858], p. 314.

93 Urrejola (1860).

94 V. gr., Herederos de Chopitea (1854); Argomedo (1854); González (1854); Testamentaria de Cardemí (1854); Correa (1856); Muñoz (1856); Vildósola y Hermanos (1856); Tesorero de los Establecimientos de Beneficencia con el Fisco (1856); Fernández Beltrán (1856); Herederos de Del Sol (1856); Herederos de Ascasivar (1856); Herederos de Villanueva (1857); Herederos de Soffia (1857); Ocón (1858); Tesorero de los establecimientos de beneficencia con Fernández Beltrán (1859); Aguirre Solarte (1860).
} 
(2), la situación de sus frutos (3), las eventuales compensaciones invocadas por el Fisco (4), y las acciones que el Fisco ejerció contra autoridades administrativas que habían restituido bienes sin sentencia judicial que lo ordenase (5).

\section{Tipos de reparación}

Como es de imaginarse, la reparación preferible era la de restituir el bien que había sido secuestrado décadas antes. Esta situación se dio en causas como Herederos de Ascasivar, de $1856^{95}$.

Cuando la restitución de una especie no era posible, operaba un cumplimiento por equivalencia, prioritario, como hemos visto supra, para la ley de 1853. De varias sentencias aparecen reparaciones que involucran el valor de los bienes secuestrados, hubieran sido ellos inmuebles ${ }^{96}$, muebles ${ }^{97}$, o ambos ${ }^{98}$.

También debían ser indemnizadas las cantidades que habían sido empleadas por el Fisco para hacer efectivo el secuestro y que hubieran procedido de bienes de las víctimas de este. Tal es el caso del premio pagado, con los bienes secuestrados a un enemigo político, a quien lo hubiese delatado ${ }^{99}$.

2. Determinación del valor de los bienes

Para determinar el valor de los bienes, se tomaba fuertemente en cuenta el que ellos habían tenido al momento de su aprehensión por parte de las autoridades administrativas; solo si no existía constancia del valor en tal momento se tomaba en cuenta el que hubiera tenido en un momento posterior, como el de su enajenación a un tercero ${ }^{100}$.

En este contexto, resulta de extraordinario interés la sentencia Herederos de Del Sol, de 1856, una de las más llamativas de todas cuantas se emitieron en esta materia. Las autoridades patrias, al apoderarse de los bienes de don Antonio del Sol, secuestraron también un conjunto de documentos - "escrituras", en el vocabulario de la sentencia- que representaban créditos contra diversos deudores y que no fueron cobrados dentro de los plazos legales.

Al trabarse el juicio en la década de 1850, los Ministros del Tesoro alegaron que dichos títulos ya no tenían valor, por hallarse prescritas todas las acciones tendientes al cobro de las sumas que representaban. La sentencia del juzgado de letras recaída sobre este pleito expresó lo siguiente: " $3^{\circ}$ que las escrituras de que se trata si bien no fueron dinero real y efectivo, lo representaban, y el fisco dueño de ellas, en virtud del embargo debió realizarlas:

95 Herederos de Ascasivar (1856).

96 Argomedo (1854).

97 Por ejemplo, un barco y las mercaderías que contenía, Herederos de Villanueva (1857); ganado, Herederos de Soffia (1857); joyas (partida segunda), Ocón (1858).

98 Fernández Beltrán (1856).

99 Herederos de Chopitea (1854).

100 Fernández Beltrán (1856). El considerando primero de la sentencia de la Corte Suprema señala lo siguiente: "que el valor de la chácara de Manquegua se entienda por treinta y seis mil ochocientos cincuenta pesos doce centavos en que fue subastada en el año de 1825, en atención a que no hay constancia en el proceso del estado en que la recibió el Fisco en el año de 1817, y a que es probable que hubiese aumentado su valor con el tiempo transcurrido hasta la ejecución". 
$4^{\circ}$ que la morosidad, negligencia o descuido de los representantes del Erario Nacional, o las concesiones que el Supremo Gobierno hizo a algunos deudores, no deben perjudicar a los herederos de Sol, que nada podían hacer para cobrar esas escrituras", para finalmente ordenar que les fueran consolidadas las sumas respectivas, lo que fue confirmado por la $\mathrm{Su}$ prema Corte ${ }^{101}$.

En todo caso, tanto en este caso de títulos de crédito, como tratándose de dinero ${ }^{102}$, las restituciones respondieron a un criterio de valor nominal, y no real. La ley de 1853, al aludir en sus artículos $16^{103}, 17^{104}$ y $18^{105}$ a intereses y capitales amortizados, se refería a la deuda ya consolidada, es decir, al monto ya calculado y declarado como tal por el competente tribunal.

\section{Frutos}

Los frutos de los bienes secuestrados en general no eran debidos por el Fisco ${ }^{106}$; pero de haberse dictado sentencia definitiva que declarase pertenecer la cosa a un particular, el Fisco debía responder por ellos desde la fecha de la sentencia que se la atribuyese. En este sentido contamos con una causa interesante, en la que los tribunales declararon en primer lugar pertenecerle a la recurrente una cuota del inmueble, el resto siendo de propiedad del Fisco; y posteriormente declararon que la totalidad del inmueble le pertenecía al particular. Las sumas percibidas por el Fisco respecto del inmueble a cualquier título entre las sentencias primera y segunda debían ser restituidas al particular por la porción del predio de que era propietario; y a partir de la segunda, le debían ser restituidas en su totalidad ${ }^{107}$.

Cabe subrayar que no fueron considerados como frutos las sumas procedentes de las ventas de escombros de casas que se arruinaron después de su aprehensión por parte de la Administración. En consecuencia, su restitución no era considerada un bis in idem cuando el tribunal también ordenaba la restitución del predio del que procedían ${ }^{108}$.

\section{Compensaciones}

Al consolidar la deuda, los tribunales de justicia podían deducir del monto debido al particular que había obtenido en el juicio todas aquellas sumas que, por una u otra razón, corrían como créditos en beneficio del Fisco, siempre que tuvieran alguna relación con el secuestro.

\footnotetext{
101 Herederos de Del Sol (1856).

102 Véase González (1854) y Herederos de Villa-Campa (1859).

103 "Se asigna a la deuda consolidada el interés anual del tres por ciento que se pagará en cuatro dividendos desde el día 8 hasta el 12 de los meses de enero, abril, julio y octubre de cada año".

104 "Se establece como capital amortizante el medio por ciento anual sobre la suma de la deuda consolidada".

105 "La amortización se efectuará por trimestres en los últimos días de cada uno de los meses designados para el pago de intereses. Se verificará por propuestas cerradas”.

106 Tesorero de los Establecimientos de Beneficencia con el Fisco (1856).

107 Testamentaria de Cardemí(1854).

108 Herederos de Ascasivar (1856): "los cuatrocientos veinte y tres pesos seis y tres octavos reales, producto de la venta de los materiales de la casa arruinada, no puede considerarse como fruto de ella percibido por el fisco, sino que es valor del mismo edificio que constituía parte integrante del secuestro, el que existe depositado en arcas fiscales".
} 
Así, fueron compensadas sumas pagadas o entregadas a los recurrentes por distintos conceptos, mesadas inclusive, a partir de los bienes secuestrados ${ }^{109}$; pero también se dieron operaciones más sofisticadas, como la compensación de las sumas correspondientes a los derechos de internación que antaño hubieran pagado las mercaderías si no hubieran sido secuestradas antes de su ingreso ${ }^{110}$.

5. Reparación pedida por el Fisco a antiguas autoridades que hubieron restituido secuestros

Por último, cabe señalar que se dieron casos de demandas dirigidas por el Fisco contra aquellas autoridades administrativas que dispusieron la restitución de los bienes secuestrados a sus antiguos propietarios sin sentencia judicial que la ordenase, por las que los representantes del Erario pedían el resarcimiento de las cantidades que el Estado había dejado de percibir en razón de la restitución.

Tal fue el objeto de una sentencia Fisco con Serrano, que juzgó el caso en que los Ministros del Tesoro habían interpuesto acción contra el Intendente de la Provincia de Concepción, Domingo Urrutia, por haber este restituido una finca que por ello había dejado de producir cánones de arrendamiento para el Estado.

La Corte entendió que "no parece legal ni es de equidad hacer gravar la responsabilidad de ese mismo canon a quien, como el ex Intendente Urrutia, no tuvo provecho alguno, al dar cumplimiento a una orden Suprema; mucho más no habiendo procedido con malicia en la manera como la entendió y ejecutó" ${ }^{111}$. La autoridad administrativa se hallaba por lo tanto cubierta en caso de mediar una orden procedente del Presidente de la República. Cabe preguntarse, en todo caso, si las consideraciones de equidad y de buena fe expresadas en la sentencia hubieran podido operar en caso de el Intendente hubiera restituido el bien sin previa orden suprema.

\section{CONCLUSIÓN}

1. Los secuestros de bienes efectuados durante el proceso independentista dieron lugar a una de las categorías fundacionales de la responsabilidad del Estado de Chile. 2. En la construcción de este régimen de responsabilidad por los daños derivados de secuestros pueden advertirse tres etapas sucesivas:

a) En primer lugar, una etapa retributiva -marcada por el Senadoconsulto de 5 de mayo de 1821- cuya finalidad era recompensar a la víctima que enmendase su postura política y se convirtiese al régimen independiente de gobierno, o restituir bienes a quienes erróneamente hubieran sido considerados como enemigos políti$\cos ($ I.a);

09 Vildósola y Hermanos (1856); Tesorero de los Establecimientos de Beneficencia con el Fisco (1856); Tesorero de los establecimientos de beneficencia con Fernández Beltrán (1859).

110 Herederos de Villanueva (1857).

111 Fisco con Serrano (1855). 
b) En segundo lugar, una etapa transitoria -marcada por la Ley de Deuda Interior, de 17 de noviembre de 1835- en la que a la posición retributiva le fueron superpuestos criterios objetivos de reparación, que no lograron desplegarse totalmente en razón de estar pendiente la entrada en vigor de una legislación que los ejecutase en cuanto a los créditos derivados de secuestros (I.b); y

c) En tercer lugar, una etapa plenamente reparatoria -marcada por la Ley de Secuestros, de 15 de septiembre de 1853- cuya finalidad fue la de resarcir los desequilibrios jurídicos producidos por estas confiscaciones políticas, atendiendo meramente al daño injusto que la víctima había padecido (II).

3. La última etapa de la responsabilidad por daños derivados de secuestros fue además definitiva, pues el artículo 13 de la ley de 1853, reiterando el plazo de cuatro años anticipado por el artículo $6^{\circ}$ del Tratado de 1844 celebrado entre Chile y España, dispuso la imposibilidad de abrir juicios en esta materia después del 15 de septiembre de 1857; en este sentido, merece destacarse el hecho de que las funciones Ejecutiva, Legislativa y Judicial se hayan mostrado contestes en que, aproximadamente cuarenta años después de la ejecución de los secuestros, los daños injustos derivados de ellos merecían aún ser reparados. Este marco jurídico de reparación sirvió, a su vez, a cumplir con un propósito político: consolidar definitivamente la Emancipación de Chile.

\section{BIBLIOGRAFÍA}

Actas del Consejo de Estado de la República de Chile (Actas CE).

Boletín de Leyes y de Decretos del Gobierno (BLDG).

Discursos de apertura en las Sesiones del Congreso y Memorias Ministeriales. Tomo IV. Imprenta del Ferrocarril. Santiago. 1858.

Sesiones de los Cuerpos Legislativos de la República de Chile (SCL, recopilación de LETELIER, Valentín).

Sesiones del Congreso Nacional (SCN).

Barros Arana, Diego (2005): Historia General de Chile. Tomo XII (Santiago, Editorial Universitaria).

Cárdenas Gueudinot, Mario (1998): Consecuencias económicas y sociales del proceso de emancipación en Chile: el caso de los secuestros de bienes a patriotas y realistas, 1813-1853 (Tesis para optar al grado de doctor en historia, Pontificia Universidad Católica de Chile, 1998, inédita).

Dávila Campusano, Óscar (1988): El secuestro de bienes en la Independencia de Chile (Memoria para optar al grado de licenciado en ciencias jurídicas y sociales, Universidad de Chile, inédita).

EnCina, Francisco Antonio (1970): Historia de Chile desde la prehistoria hasta 1891 (Santiago, Nascimento, Tercera edición).

Guerrero Lira, Cristián (2002): La contrarrevolución de la Independencia en Chile (Santiago, Editorial Universitaria). 
Silva Vargas (2013): “Los primeros pasos del gobierno de O’Higgins después de Chacabuco", en Silva Vargas (edit.), Historia de la República de Chile. Volumen I. El fin de la monarquia y los orígenes de la República (Santiago, Zig-Zag) pp. 389-437.

Westermeyer Hernández, Felipe (2010): "La desamortización de los bienes de regulares en Chile: la primera discusión jurídica del derecho patrio sobre la naturaleza y alcance del dominio", Revista Chilena de Historia del Derecho, vol. nº 22 (2010), pp. 11031129.

\section{NORMAS CITADAS}

Decreto [Senadoconsulto] de Amnistía, de 8 de febrero de 1819.

Senadoconsulto de 5 de mayo de 1821 .

Decreto de 10 de julio de 1827.

Decreto de 15 de enero de 1828.

Decreto de 10 de octubre de 1828.

Decreto de 3 de abril de 1829.

Ley de 14 de septiembre de 1830 .

Ley de 17 de noviembre de 1835.

Ley de 2 de febrero de 1837.

Ley de 7 de febrero de 1837.

Decreto-ley de 14 de febrero de 1837.

Decreto-ley de 3 de abril de 1839.

Decreto Supremo de 23 de noviembre de 1841.

Tratado de Paz y Amistad entre Chile y España, de 25 de abril de 1844.

Ley de 15 de septiembre de 1853.

Ley de 19 de junio de 1858.

\section{JURISPRUDENCIA CITADA}

Pantoja (1817): Gobernador Intendente de Concepción, 23 de octubre de 1817, JC 19 pieza 5 , f. 5 vta.

Vela (1818): Cámara de Apelaciones, 12 de noviembre de 1818, RA 1027 pieza 3 (transcrita en causa De la Cruz), f. 91 vta.

Cardemi (1819): Gobernador Intendente de Santiago, $1^{\circ}$ de febrero de 1819, CG 49 pieza 25, f. 16.

Buzeta (1821): Gobernador Intendente de Santiago, 31 de marzo de 1821, JS 1119, pieza 8, f. 9 vta.

Recabarren (1821): Gobernador Intendente de Concepción, 26 de junio de 1821, JC 183 pieza 10, f. 40.

Zapata (1823): Gobernador Intendente de Santiago, 28 de marzo de 1823, JS 367 pieza 1, f. 5. Olave (1823): Junta Superior de Hacienda, 30 de octubre de 1823, JS 693 pieza 13, f. 41 vta. Fisco con Ruiz (1825): Juzgado de letras de Concepción, 12 de enero de 1825, JC 85 pieza 4, f. 75 vta. 
Beltrán (1827): Corte Suprema, 27 de mayo de 1827, JS 140 pieza 7, f. 1 (transcripción en causa posterior).

Vildósola (1828): Corte de Apelaciones, 15 de febrero de 1828, RA 2114 piezas 1 y 3, f. 30 vta. Ministros del Tesoro con Ávila (1830): Corte de Apelaciones, 26 de febrero de 1830, JS 643 pieza 2, f. 51 vta.

Freire (1831): Corte de Apelaciones, 30 de abril de 1831, JS 378 pieza 2, f. 121.

Pozo (1833): Corte de Apelaciones, 5 de julio de 1833, JS 772 pieza 6, f. 39 vta.

Villaurrutia (1838): Corte Suprema, 5 de septiembre de 1838, JS 1007, pieza 5, f. 231.

García (1840): Corte Suprema, 4 de agosto de 1840, JS 1235, pieza 6, f. 57.

Freire (1843): Corte Suprema, 2 de mayo de 1843, Gaceta de los Tribunales, n ${ }^{\circ} 70$ (1843), p. 1.

Herederos de Chopitea (1845): Corte Suprema, 8 de abril de 1845, Gaceta de los Tribunales, no 162 (1845), p. 82.

Beltrán (1847): Corte Suprema, 21 de diciembre de 1847, Gaceta de los Tribunales no 298 (1848), p. 1583

Navajete (1848): Corte Suprema, 17 de octubre de 1848, Gaceta de los Tribunales no 336 (1848), p. 1990.

Herederos de Urrejola (1853): Corte Suprema, 13 de diciembre de 1853, Gaceta de los Tribunales no 593 (1853) p. 4749.

Herederos de Chopitea (1854): Corte Suprema, 8 de agosto de 1854, Gaceta de los Tribunales no 627 (1854) p. 5277.

Argomedo (1854): Corte Suprema, 21 de agosto de 1854, Gaceta de los Tribunales no 629 (1854) p. 5309.

González (1854): Corte Suprema, 17 de noviembre de 1854, Gaceta de los Tribunales no 641 (1854) p. 5501.

Testamentaria de Cardemí (1854): Corte Suprema, 5 de diciembre de 1854, Gaceta de los Tribunales no 644 (1854) p. 5545.

Fisco con Serrano (1855): Corte Suprema, 29 de mayo de 1855, Gaceta de los Tribunales no 669 (1855) p. 5915.

Correa (1856): Corte Suprema, 8 de febrero de 1856, Gaceta de los Tribunales no 705 (1856) p. 6489.

Muñoz (1856): Corte Suprema, 19 de febrero de 1856, Gaceta de los Tribunales no 707 (1856), p. 6510.

Vildósola y Hermanos (1856): Corte Suprema, 7 de marzo de 1856, Gaceta de los Tribunales no 709 (1856) p. 6543.

Tesorero de los Establecimientos de Beneficencia con el Fisco (1856): Corte Suprema, 4 de junio de 1856, Gaceta de los Tribunales no 722 (1856) p. 6751.

Fernández Beltrán (1856): Corte Suprema, 5 de agosto de 1856, Gaceta de los Tribunales no 731 (1856) p. 6894.

Vicuña (1856): Corte Suprema, 26 de agosto de 1856, Gaceta de los Tribunales no 734 (1856) p. 6941.

Herederos de Del Sol (1856): Corte Suprema, 14 de octubre de 1856, Gaceta de los Tribunales no 741 (1856) p. 7053. 
Herederos de Ascasivar (1856): Corte Suprema, 9 de diciembre de 1856, Gaceta de los Tribunales no 749 (1856) p. 7082.

Herederos de Villanueva (1857): Corte Suprema, 5 de mayo de 1857, Gaceta de los Tribunales no 775 (1857) p. 7500.

Herederos de Soffia (1857): Corte Suprema, 22 de mayo de 1857, Gaceta de los Tribunales no 777 (1857) p. 7532.

González (1857): Corte Suprema, 22 de septiembre de 1857, Gaceta de los Tribunales no 795 (1857) p. 7817.

Ocón (1858): Corte Suprema, 23 de marzo de 1858, Gaceta de los Tribunales no 823 (1858) p. 1.

Muñoz (1858): Corte Suprema, 16 de julio de 1858, Gaceta de los Tribunales no 837 (1858) p. 1.

Tesorero de los establecimientos de beneficencia con Fernández Beltrán (1859): Juzgado de Letras de Santiago, 17 de enero de 1859, Gaceta de los Tribunales no 874 (1859) p. 350.

Herederos de Villa-Campa (1859): Corte Suprema, 3 de junio de 1859, Gaceta de los Tribunales $\mathrm{n}^{\circ} 883$ (1859) p. 515.

Abadía (1859): Corte Suprema, 6 de diciembre de 1859, Gaceta de los Tribunales no 910 (1859) p. 1131.

Urrejola (1860): Corte Suprema, 31 de junio de 1860, Gaceta de los Tribunales no 944 (1860) p. 747.

Aguirre Solarte (1860): Corte Suprema, 16 de octubre de 1860, Gaceta de los Tribunales $\mathrm{n}^{\circ}$ 955 (1860), p. 1010. 
